ER R ATA

\title{
Erratum: The catalytic cycle of a thiamin diphosphate enzyme examined by cryocrystallography
}

Georg Wille, Danilo Meyer, Andrea Steinmetz, Erik Hinze, Ralph Golbik \& Kai Tittmann

Nat. Chem. Biol. 2, 324-328 (2006); published online 7 May; corrected after print 30 May 2006

In the version of this article initially published, there was an error in the text of the second page. In line 15 of the first column, the text should read "a difference Fourier" rather than "a distance Fourier." The error has been corrected in the PDF version of the article. 